\title{
CORRELATIONS OF DEOXYRIBONUCLEIC ACID METHYLATION, HISTONE ACETYLATION, AND MICRORNA-320 WITH SORBITOL DEHYDROGENASE IN DIABETIC RETINOPATHY
}

\author{
RAMZI AMIN ${ }^{1 *}$, DANY HILMANTO ${ }^{2}$, ARIEF S. KARTASASMITA ${ }^{3}$, HIKMAT PERMANA ${ }^{4}$ \\ ${ }^{1}$ Department of Ophthalmology, Sriwijaya University, Palembang, Indonesia. ${ }^{2}$ Department of Paediatric Health, Padjajaran University, \\ Bandung, Indonesia. ${ }^{3}$ Department of Ophthalmology, Padjajaran University, Bandung, Indonesia. ${ }^{4}$ Department of Internal Medicine, \\ Padjajaran University, Bandung, Indonesia. Email: dr.rachmat.hidayat@gmail.com
}

Received: 14 November 2018, Revised and Accepted: 19 December 2018

ABSTRACT

Objective: Prolonged and persistent hyperglycemia in diabetes mellitus (DM) leads to a variety of vascular complications, including the retinal disorder of diabetic retinopathy (DR). The mechanism of fructose formation of sorbitol assisted by sorbitol dehydrogenase (SDH) causing the loss of pericytes in the blood vessel is affected by epigenetic work comprised of deoxyribonucleic acid (DNA) methylation, histone acetylation, and microRNA-320. This study aimed to determine the correlation of DNA methylation, histone acetylation, and microRNA-320 with SDH in DR.

Methods: This case-control study was conducted at a tertiary general hospital from July 2014 to June 2016. Study subjects were type 2 DM patients with and without DR, over 40 years old, suffered from DM for $>10$ years. DNA methylation, histone acetylation, and microRNA-320 were examined by real-time quantitative polymerase chain reaction, while SDH level examination was carried out by enzyme-linked immunosorbent assay. Analyses were performed with independent t-test, Mann-Whitney, Spearman correlation, and multiple linear regression.

Results: With respect to SDH, DNA methylation showed no significant correlation so as histone acetylation, in contrary to microRNA-320 with a very strong negative correlation $(\mathrm{r}=-0.968, P<0.005)$.

Conclusion: MicroRNA-320 was correlated to SDH in a manner of protective properties against the occurrence of DR. Involvement of DNA methylation and histone acetylation was perceptible in influencing SDH enzyme despite their insignificance if they took place individually.

Keywords: Diabetic Retinopathy, Deoxyribonucleic acid methylation, Histone acetylation, MicroRNA-320, Sorbitol dehydrogenase enzyme.

(C) 2019 The Authors. Published by Innovare Academic Sciences Pvt Ltd. This is an open access article under the CC BY license (http://creativecommons. org/licenses/by/4. 0/) DOI: http://dx.doi.org/10.22159/ajpcr. 2019.v12i2.30755

\section{INTRODUCTION}

Diabetes mellitus (DM) is a chronic disease characterized by an elevated plasma glucose level or hyperglycemia due to impaired insulin secretion and/or insulin resistance. Prolonged and persistent hyperglycemia in DM leads to a variety of vascular complications, in which one of the microvascular complications is a major cause of vision problems worldwide, diabetic retinopathy (DR) [1-3]. The number of DM sufferers worldwide in 2000 was around 171 million, and it is estimated that, by 2030, it will reach 366 million. Complication of DM aside from blindness is increased overall health financing. In United States (US), the cost for the treatment and prevention of DM and its complications is estimated to reach US $\$ 490$ billion in $2030[1,4,5]$.

Retinal vascular disorders occur as a result of hyperglycemia through the pathways of polyols, protein kinase C (PKC), advanced glycation end products (AGEs), hexosamine, and oxidative stress. Excessive reactive oxygen species (ROS) causes reduced pericytes, microaneurysms, exudates, edema, and bleeding around the retina, eventually leading to blindness [6-8]. In addition to the loss of pericytes, there is also another role for ROS to damage retinal endothelial cells. Damage to retinal endothelial cells is also exacerbated by an increase in AGEs production due to hyperglycemia $[6,9]$.

Blindness is not only related to the role of sorbitol dehydrogenase (SDH) and nicotinamide adenine dinucleotide phosphate co-factor but also other factors such as genetic or epigenetic. Genetics influence the level of methylation of deoxyribonucleic acid (DNA), acetylation of histones, and ribonucleic acid (RNA). Examination is suggested on the role of DNA methylation, histone acetylation, and microRNA-320 with SDH enzyme in type 2 DM patients with a complication of retinopathy as an early detection of DR to prevent permanent blindness. This study aimed to determine the correlation between DNA methylation, histone acetylation, and microRNA-320 with SDH in DR.

\section{METHODS}

This case-control study was carried out in the Eye Polyclinic of Vitreoretina, Mohammad Hoesin General Hospital, Palembang, Indonesia, from July 2014 to June 2016. Consents from participants were legitimated by signing an informed consent. This study obtained ethical approval from the health research ethics committee (094/UN6. C1.3.2/KEPK/PN/2015). DM was defined as a condition with fasting plasma glucose level of $>120 \mathrm{mg} / \mathrm{dl}$ and postprandial of $>200 \mathrm{mg} / \mathrm{dl}$ and had endured from DM for $>5$ year. Ophthalmoscopy findings (Neitz Instruments Co., Ltd., Japan) of microaneurysms, exudates, bleeding, and neovascularization were defined as DR.

\section{Patients' eligibility}

The study subjects were DR patients at an Eye Polyclinic of Vitreoretina Subdivision, aged over 40 years, who had experienced DM for $>10$ years, as cases. Age- and gender-matched DM patients without non-DR (NDR) were selected as controls. Patients with leukemia retinopathy, retinitis pigmentosa, and chorioretinitis were excluded from the study.

\section{Blood specimen preparation}

As many as $5 \mathrm{ml}$ of venous blood specimens was withdrawn and put into ethylenediaminetetraacetic acid (EDTA) tubes for DNA and RNA isolation and non-EDTA tubes for SDH enzyme-linked immunosorbent assay (ELISA).

DNA methylation (Abcam plc., Cambridge, UK), histone acetylation (Abcam plc., Cambridge, UK), and microRNA-320 were examined by real-time quantitative polymerase chain reaction (RT-qPCR) (Bio-Rad Laboratories, Inc., California, USA), while SDH level examination (Cloud-Clone Corp., 
Texas, USA) was carried out by ELISA (Bio-Rad Laboratories, Inc., California, USA).

\section{DNA methylation examination}

A single point control was made by diluting the positive control. The addition of $80 \mu \mathrm{l}$ binding solution and $1 \mu \mathrm{l}$ DNA sample at each well was performed before incubation for $90 \mathrm{~min}$ at $37^{\circ} \mathrm{C}$, followed by washing and addition procedures for $50 \mu \mathrm{l}$ of capture antibody, $50 \mu \mathrm{l}$ detection antibody, and $50 \mu \mathrm{l}$ of diluted solution enhancer. Methylated DNA observation was carried out by the addition of $100 \mu \mathrm{l}$ developer solution. Sufficient methylated DNA was marked by blue color alteration. The color turned yellow after the addition of $50 \mu$ l of stop solution and absorbance was examined on the microplate reader at $450 \mathrm{~nm}$.

\section{Histone acetylation examination}

Histone extraction was performed starting from the addition of $10 \mu \mathrm{l}$ lysis buffer and $300 \mu \mathrm{l}$ extraction buffer in $100 \mu \mathrm{l}$ blood samples. After $12,000 \mathrm{rpm}$ centrifugation for $5 \mathrm{~min}$ at $4^{\circ} \mathrm{C}$, the supernatant was taken and followed by the addition of trichloracetic acid $100 \%$ with a ratio of 1:4, followed by washing with $1 \mathrm{ml}$ acetone, then centrifuged at $1200 \mathrm{rpm}$ for $2 \mathrm{~min}$ at $4^{\circ} \mathrm{C}$. The supernatant was then discarded to obtain pellets, and the pellets were dissolved with $10 \mu \mathrm{l}$ of distilled water. Each sample was processed with $5 \mu \mathrm{l}$ histone buffer, $150 \mu \mathrm{l}$ blocking buffer, and $50 \mu \mathrm{l}$ diluted captured antibody. Readings at a wavelength of $450 \mathrm{~nm}$ were carried out after the samples were processed with developing solution and stop solution.

\section{MicroRNA-320 examination}

RNA isolation was performed before complementary DNA (cDNA) synthesis with $2 \mu \mathrm{l} \times 5$ reaction buffer, $4.5 \mu \mathrm{l}$ nuclease free water, $1 \mu \mathrm{l}$ enzyme mix, $0.5 \mu \mathrm{l}$ RNAse, and $2 \mu \mathrm{l}$ RNA sample. Incubation for $60 \mathrm{~min}$ was carried out at $42^{\circ} \mathrm{C}$ and then for $5 \mathrm{~min}$ at $95^{\circ} \mathrm{C}$ followed by storing in the refrigerator at $4^{\circ} \mathrm{C}$. Dilution of cDNA was performed with nuclease-free water with a ratio of 1:80. RT-qPCR was performed.

\section{SDH examination}

SDH examination was initiated with the preparation of standards with standard solutions and standard dilution buffers. After the samples were transferred into each well, incubation was carried out for $30 \mathrm{~min}$ at $37^{\circ} \mathrm{C}$, followed by dilution of the washing buffer and washing procedures. Horseradish peroxidase conjugate reagent of $50 \mu \mathrm{l}$ was added, followed by staining with $50 \mu \mathrm{l}$ of chromogen solution $\mathrm{A}$ and $50 \mu \mathrm{l}$ of chromogen solution $\mathrm{B}$, and terminated with $50 \mu \mathrm{l}$ stop solution. Color alteration of blue to yellow was observed. Absorbance was read on a microplate reader at $450 \mathrm{~nm}$.

\section{Data analysis}

Before statistical tests on numerical data, normality tests were assessed using Kolmogorov-Smirnov. To compare the two groups in a numerical scale, independent $t$-test was used for normally distributed data and otherwise with Mann-Whitney. Analysis for the correlation between variables was performed with Spearman correlation. Interpretation of the results was based on correlation strength, direction, and level of significance. Correlation strength (r) was based on Guillford (1956) criteria. The significance level was $P<0.05$. The data obtained were recorded in a form and processed with SPSS 21.0 (SPSS Inc., Chicago, USA).

\section{RESULTS}

The study subjects were comprised of 40 DR and 40 NDR patients obtained consecutively. There were no significant differences present on age, gender, and blood pressure between DR and NDR groups as shown in Table 1. Nevertheless, the DR group exhibited slight older mean of age and larger number of participant with normal blood pressure (systolic blood pressure $<140 \mathrm{mmHg}$ and diastolic $<90 \mathrm{mmHg}$ ) compared to NDR. Both groups of DR and NDR consisted of the same number of male and female participants. There were no significant differences in DNA methylation and histone acetylation between DR and NDR groups. Nevertheless, DR group exhibited lower DNA methylation and higher histone acetylation, whereas, for microRNA-320 and SDH, significant differences were observed between DR and NDR groups. MicroRNA-320 copy for DR was found to be lower compared to NDR group. DR group exhibited higher SDH level compared to NDR.

In bivariate analysis, with respect to $\mathrm{SDH}$ of DR patients, there was a very weak positive relationship with DNA methylation and a very weak negative correlation with histone acetylation as shown in Table 2 . There was a significant very strong negative correlation between microRNA-320 and SDH of DR patients, where the lower microRNA-320 provoked higher SDH and vice versa. Based on multivariate analysis as shown in Table 2, with respect to SDH of DR patients, there was a very weak positive correlation with DNA methylation and histone acetylation. However, there was a significant strong negative correlation between microRNA-320 and SDH of DR patients.

\section{DISCUSSION}

In this study, the incidence of DR was at mean age of $56.88 \pm 6.35$ years and the NDR group $54.30 \pm 4.83$ years. Other studies discovered the average age affected by DR which was between 40 and 65 years [10]. In a multicenter study in Mexican-American, it was found that the average age of 60-69 years suffered more from DR [2,3]. Of all type 2 DM patients, $23 \%$ suffers from non-proliferative DR after 5-13 years, $41 \%$ after $14-16$ years, and $60 \%$ after 16 year [4,7,11-13].

In the gender of DR and NDR participants in this study, female dominated over male in number. Similar to a multicenter study in Mexican-American, those affected by DR were $37.3 \%$ of men and $62.7 \%$ of women $[2,3]$. On subjects with the age as in this study, high

Table 1: Baseline characteristics

\begin{tabular}{|c|c|c|c|}
\hline Characteristics & Diabetic retinopathy (DR) $(n=40)$ & Non-diabetic retinopathy (DR) $(n=40)$ & p-value \\
\hline \multicolumn{4}{|l|}{ Age (year) } \\
\hline Mean \pm SD & $56.88 \pm 6.35$ & $54.3 \pm 4.83$ & $0.140^{\mathrm{a}}$ \\
\hline \multicolumn{4}{|l|}{ Gender } \\
\hline Male n(\%) & $11 / 40(27.5)$ & $11 / 40(27.5)$ & $1.000^{\mathrm{b}}$ \\
\hline Female n(\%) & $29 / 40(72.5)$ & $29 / 40(72.5)$ & \\
\hline \multicolumn{4}{|l|}{ Blood pressure } \\
\hline Normal n (\%) & $29 / 40(72.5)$ & $26 / 40(65.0)$ & $0.630^{\mathrm{b}}$ \\
\hline \multicolumn{4}{|l|}{ DNA methylation (\%) } \\
\hline Median (min-max) & $19.9(11.2-126.37)$ & $29.5(10.1-82.13)$ & $0.256^{\mathrm{a}}$ \\
\hline \multicolumn{4}{|l|}{ Histone acetylation (\%) } \\
\hline Median (min-max) & $9.29(5.61-25.27)$ & $7.99(6.69-29.69)$ & $0.758^{\mathrm{a}}$ \\
\hline \multicolumn{4}{|l|}{ MicroRNA-320 (copy) } \\
\hline Mean \pm SD & $11.74 \pm 1.04$ & $12.29 \pm 0.81$ & $0.010^{\mathrm{b} *}$ \\
\hline \multicolumn{4}{|l|}{$\mathrm{SDH}(\mathrm{pg} / \mathrm{ml})$} \\
\hline Median (min-max) & $11.69(6.16-54.60)$ & $10.78(6.55-15.69)$ & $0.044^{\mathrm{a} *}$ \\
\hline
\end{tabular}


Table 2: Correlation between DNA methylation, histone acetylation, microRNA-320, and SDH in DR

\begin{tabular}{lllll}
\hline Variable & \multicolumn{4}{l}{ Sorbitol dehydrogenase (SDH) } \\
\cline { 2 - 5 } & $\mathbf{r S}$ & $\mathbf{p}$ value & $\mathbf{r}$ & p value \\
\hline DNA methylation & 0.153 & $0.345^{\mathrm{a}}$ & 0.104 & $0.359^{\mathrm{b}}$ \\
Histone acetylation & -0.139 & $0.393^{\mathrm{a}}$ & -0.018 & $0.871^{\mathrm{b}}$ \\
MicroRNA-320 & -0.968 & $<0.005^{\mathrm{a} *}$ & -0.727 & $<0.005^{\mathrm{b} *}$ \\
\hline
\end{tabular}

DNA: Deoxyribonucleic acid, RNA: Ribonucleic acid, a'Spearman correlation,

${ }^{b}$ Multiple linear regression, ${ }^{*} \mathrm{p}<0.05, \mathrm{SDH}$ : Sorbitol dehydrogenase

possibility of female participants entering menopause was observed with hormonal factors aggravated the onset of retinopathy [14].

Less DR occurred at younger age without hypertension as observed in this study. The occurrence of DR depends on retinal blood vessel abnormalities. Pathogenesis of hypertensive retinopathy and DR is distinct. One is the damage due to peripheral vascular pressure and the other is the damage to the endothelial wall and pericyte. A study discovered that any reduction in systolic blood pressure by $10 \mathrm{mmHg}$ was equivalent to a reduced risk of retinopathy by $40 \%[7,11-13]$.

The mean of DNA methylation in DR group was lower compared to NDR. It was assumed that there was an inhibition of DNA methylation so that gene expression increased to form an enzyme, in this case, SDH. DNA methylation affects gene transcription in two ways. First, DNA methylation itself physically inhibits the binding of transcriptional proteins to genes. Second and perhaps more importantly, methylated DNA is bound by proteins known as methyl-CpG binding proteins. This protein then recruits additional proteins to the locus, such as histone deacetylase and other remodeling protein chromatin which can modify histones, thus forming inactive and less accessible chromatin for transcription processes $[15,16]$. The binding proteins also form complexes with proteins involved in histone deacetylation. Therefore, when DNA is methylated, the nearby histones will be acetylated and produced a compound inhibitory effect on transcription. Likewise, demethylated DNA does not attract deacetylation enzymes to the histones, thus allowing them to remain mobile and encouraging transcription $[17,18]$.

On histone acetylation examination, the mean histone acetylation in DR group was greater compared to NDR. In another study of in vitro and in vivo, increased histone deacetylation and decreased histone acetyltransferase were exhibited, which participated in acetylation of the retina and capillary cells. Contrary to this, Kadiyala et al. as quoted in Kowluru et al. showed an increase in histone acetylation in diabetes [14]. Histone itself is divided into four, where the one used in this study was histone acetylation of H3. The results obtained histone acetylation of DR group was of higher value, although it was not statistically significant. It was assumed that there was another histone role that affected this histone acetylation. One of them was histone methylation, in a contrary manner, as a factor of repression. Several other factors were assumed to likely influence the results of H3 acetylation in this study. Examining other histones might better illustrate the pattern of this histone work.

Another epigenetic work examined was microRNA. In this study, microRNA-320 was used specifically for SDH enzymes. In microRNA-320 examination, the mean of DR group was lower compared to NDR. In the analysis, it was assumed that microRNA was a protective factor. This was interpreted that the greater level of microRNA provoked greater protective properties against the occurrence of DR. MicroRNA-320 possesses a broad range of biological effects because it regulates several important molecules. The main targets include expression of endothelin (ET-1), extracellular signal-regulated kinase1, vascular endothelial growth factor (VEGF), and fibronectin. Its biological actions include the effects on carcinogenesis, development, and reperfusion injury for ischemia. MicroRNA-320 expression increases and consequently a decrease in insulin-like growth factor 1 (IGF-1) and IGF-1R expression tends to play a role in angiogenesis disorders observed in diabetes [19].

In this study, SDH level in DR group was higher compared to NDR. DR was associated with altered retinal configuration as observed in the $\mathrm{NH}-\mathrm{OH}, \mathrm{CH}$, and fingerprint regions in Fourier-transform infrared spectroscopy bands [20]. Damages or apoptosis in retinal cells is caused by elevated osmotic activity in the retina. This osmotic increase is caused by the role of the polyol pathway. In polyol pathway, aldose reductase (ALR) is the initial enzyme catalyzing the conversion of glucose to sorbitol, followed by the conversion of sorbitol to fructose by SDH. The sorbitol attenuates cellular homeostasis, followed by oxidative damage causing reduced pericytes, microaneurysms, exudates, edema, and bleeding around the retina [6-8]. A study by Dongare et al. exhibited that ALR and VEGF-165 messenger RNA (mRNA) expression analyzed by RT-PCR were increased with high concentration of glucose [21]. In another study, Preston et al. obtained that serum levels of sorbitol were elevated after meal, in accordance with the mechanism of hyperglycemia [22]. Higher SDH enzyme level in DR group of this study exhibited an increase in gene expression of SDH enzyme in the DR group, eventually leading to retinal vascular damage.

In multivariate analysis of this study, a correlation between microRNA-320 and SDH was observed. Although, in this multivariate analysis, histone acetylation and DNA methylation did not possess significant roles in elevating SDH enzyme, their interaction with microRNA-320 would still lead to DR. DNA methylation, histone acetylation, and micro-320 RNA are non-coding factors that contribute to DR so that prevention of DR can be exerted by examining these factors. Further study on epigenetic factors such as histone phosphorylation and methylation, HbA1C, lipid levels, ROS, AGEs, and PKC are suggested to dissect risk factors of DR.

Limitations of this study comprised the uncollected data on subjects such as glycemic control, $\mathrm{HbA} 1 \mathrm{C}$, and the types of drugs used. This might contribute to differences in this study results. Another was the need for a third comparison in this case the population without diabetes to yield better analysis. The pathogenesis of DR was broadly complex, so this study required other epigenetic examinations such as histone methylation and histone phosphorylation. In addition, examinations of other enzymes simultaneously such as AGEs, PKC, and ROS were to obtain more accurate results. Because the processes in DR were multi-factorial, further studies are in necessity to obtain exact patterns in DR pathogenesis.

\section{CONCLUSION}

MicroRNA-320 was correlated to SDH in a manner of protective properties against the occurrence of DR. Involvement of DNA methylation and histone acetylation were perceptible in influencing SDH enzyme despite their insignificance if they took place individually.

\section{ACKNOWLEDGMENT}

All authors sincerely acknowledged the staffs of the Department of Ophthalmology, Dr. Mohammad Hoesin General Hospital, Palembang, Indonesia, for the cooperation alongside the study.

\section{AUTHORS' CONTRIBUTION}

All authors contributed equally in concepts, design, literature search, data acquisition and analysis, statistical analysis, manuscript preparation, editing, and review.

\section{CONFLICTS OF INTEREST}

All authors declared that there were no conflicts of interest.

\section{REFERENCES}

1. Zhang X, Saaddine JB, Chou CF, Cotch MF, Cheng YJ, Geiss LS, et al. Prevalence of diabetic retinopathy in the United States, 2005-2008. JAMA 2010;304:649-56. 
2. Reddy GB, Satyanarayana A, Balakrishna N, Ayyagari R, Padma M, Viswanath K, et al. Erythrocyte aldose reductase activity and sorbitol levels in diabetic retinopathy. Mol Vis 2008;14:593-601.

3. Varma R. Diabetic retinopathy: Challenges and future directions. Am J Ophthalmol 2006;141:539-41.

4. Wong TY, Klein R, Islam FM, Cotch MF, Folsom AR, Klein BE, et al. Diabetic retinopathy in a multi-ethnic cohort in the United States. Am J Ophthalmol 2006;141:446-55.

5. Aslan D. Biomarkers for diabetes complications: The results of several clinical studies. J Med Biochem 2011;30:207-12.

6. Tarr JM, Kaul K, Chopra M, Kohner EM, Chibber R. Pathophysiology of diabetic retinopathy. ISRN Ophthalmol 2013;2013:343560.

7. West SK, Munoz B, Klein R, Broman AT, Sanchez R, Rodriguez J, et al. Risk factors for Type II diabetes and diabetic retinopathy in a Mexican-American population: Proyecto VER. Am J Ophthalmol 2002;134:390-8

8. Klein R, Klein BE. The epidemiology of diabetic retinopathy. In: Ryan SJ, Schachat A, Wilkinson C, Hinton D, Sadda S, Wiedemann P, editors. Retina. $5^{\text {th }}$ ed. Baltimore: Elsevier Mosby; 2012. p. 907-24.

9. Parvanova A, Iliev I, Filipponi M, Dimitrov BD, Vedovato M, Tiengo A, et al. Insulin resistance and proliferative retinopathy: A cross-sectional, case-control study in 115 patients with Type 2 diabetes. J Clin Endocrinol Metab 2004;89:4371-6.

10. Aiello LM. Perspectives on diabetic retinopathy. Am J Ophthalmol 2003; 136:122-35.

11. Soewondo P, Ferrario A, Tahapary DL. Challenges in diabetes management in Indonesia: A literature review. Global Health 2013;9:63.
12. Jain A, Varshney N, Smith C. The evolving treatment options for diabetic macular edema. Int J Inflam 2013;2013:689276.

13. de M Bandeira S, da Fonseca LJ, da S Guedes G, Rabelo LA, Goulart MO, Vasconcelos SM, et al. Oxidative stress as an underlying contributor in the development of chronic complications in diabetes mellitus. Int J Mol Sci 2013;14:3265-84

14. Kowluru RA, Santos JM, Mishra M. Epigenetic modifications and diabetic retinopathy. Biomed Res Int 2013;2013:635284.

15. Li B, Carey M, Workman JL. The role of chromatin during transcription. Cell 2007;128:707-19.

16. Reddy MA, Zhang E, Natarajan R. Epigenetic mechanisms in diabetic complications and metabolic memory. Diabetologia 2015;58:443-55.

17. Berger SL, Kouzarides T, Shiekhattar R, Shilatifard A. An operational definition of epigenetics. Genes Dev 2009;23:781-3.

18. Miao F, Chen Z, Zhang L, Liu Z, Wu X, Yuan YC, et al. Profiles of epigenetic histone post-translational modifications at Type 1 diabetes susceptible genes. J Biol Chem 2012;287:16335-45.

19. Kantharidis P, Wang B, Carew RM, Lan HY. Diabetes complications: The microRNA perspective. Diabetes 2011;60:1832-7.

20. Aly EM. FTIR analysis for retina associated with diabetic changes and treatment with oat. Int J Pharm Pharm Sci 2015;7:277-80.

21. Dongare S, Rajendran S, Senthilkumari S, Gupta SK, Mathur R, Saxena R, et al. Genistein alleviates high glucose induced toxicity and angiogenesis in cultured human RPE cells. Int J Pharm Pharm Sci 2015;7:294-8.

22. Preston GM, Calle RA. Elevated serum sorbitol and not fructose in Type 2 diabetic patients. Biomark Insights 2010;5:33-8. 